\title{
Effect of Work Achievement, Incentives, Discipline and Leadership Style on Employee Performance
}

\section{Sri Langgeng Ratnasari ${ }^{1 *}$, Arwansyah Kirin ${ }^{2}$, Ervin Nora Susanti ${ }^{1}$, Linayati Lestari $^{1}$, Rona Tanjung ${ }^{1}$, Gandhi Sutjahjo ${ }^{3}$}

${ }^{1}$ Universitas Riau Kepulauan, Batam, INDONESIA

${ }^{2}$ Universiti Tun Hussein Onn Malaysia, 86400 Parit Raja, Batu Pahat, Johor, MALAYSIA

${ }^{3}$ Universitas Batam, Batam, INDONESIA

*Corresponding Author

DOI: https://doi.org/10.30880/jstard.2021.03.01.007

Received 30 September 2020; Accepted 30 November 2020; Available online 15 June 2021

\begin{abstract}
The purpose of this study was to analyze the effect of work performance on employee performance, to analyze the effect of incentives on employee performance, to analyze the effect of discipline on employee performance, to analyze the influence of leadership style on employee performance, and to analyze the effect of work performance, incentives, discipline, leadership style on employee performance. The population of this study were employees of PT. Austin Engineering Indonesia, amounting to 175 people in the store. The sample consisted of 175 respondents, who were taken with a saturated sampling method. Data analysis using multiple regression with SPSS. The results of this study can be concluded that work performance has a significant effect on employee performance, incentives have a significant effect on employee performance, discipline has a significant effect on employee performance, leadership style has a significant effect on employee performance. Job performance, incentives, discipline, and leadership style have a significant effect on employee performance.
\end{abstract}

Keywords: Job performance, incentives, discipline, leadership style, employee performance

\section{Introduction}

The benefits of increasing performance are felt if it has become work behavior, so that work behavior based on performance can achieve high work performance. Every employee is not necessarily able to achieve optimal work performance, so there is still a need for a driving factor in order to achieve maximum work performance. These driving factors are commonly called incentives and disciplines that can provide optimal employee performance improvements.

According to Prawirosentono (2014) states that "Performance or in English is performance", namely: Work results that can be achieved by a person or group of people in the organization, in accordance with their respective authorities and responsibilities in order to legally achieve the goals of the organization concerned., does not violate the law and is in accordance with morals or ethics. Hasibuan (2016) explains that "Performance is the result of work carried out in carrying out tasks that are assigned by order of skill, experience, seriousness and time". One of the achievements of a company is work performance. Because both the company itself and employees need feedback on their respective efforts, the work performance of each employee needs to be made. Job performance is the result of a person's efforts which are determined by correct abilities and perceptions of their role towards the job (Sutrisno, 2015).

Job performance is a result of work carried out by a person by carrying out tasks that are assigned based on skills, experience, seriousness and time (Hasibuan 2016). The thing that can improve employee performance is by providing 
incentives which are one of the main things that the company must pay attention to and that employees really want to meet their daily needs.

If the incentives provided by the company are not in accordance with the sacrifices at work, then employees tend to be lazy at work and in the end they work at will. If the provision of incentives is in accordance with what is sacrificed by employees, this will greatly help employee morale to be better and better. Because of the incentive prizes, employees will feel the results of their work and the company's concern for them.

According to Hasibuan (2016), the notion of incentives is additional remuneration given to certain employees whose performance is above standard performance. This incentive is a tool used by supporters of the fair principle in providing compensation.

According to Sofyandi (2014), incentives are a form of direct compensation. Incentives are direct rewards paid to employees because their performance exceeds the specified standard. One of the roles of an individual or employee is to carry out work discipline related to the capabilities of the employee. The ability of employees is formed from the knowledge and skills obtained from formal education institutions in general from elementary to tertiary institutions and non-formal (courses, seminars, etc.).

Hasibuan (2016), states: "Discipline is the sixth operative function of human resource management. Discipline is the most important operational function of human resource management because the better the employee's discipline, the higher the work performance they can achieve. Without good employee discipline, it is difficult for company organizations to achieve optimal results. "Thus, Hasibuan (2016) states: "Discipline is a person's willingness to obey all company regulations and prevailing social norms. Good discipline reflects the amount of responsibility a person has for the tasks assigned to him. This will encourage enthusiasm, morale, and the realization of organizational goals.

According to Thoha (2015), leadership is an activity to influence people to achieve organizational goals. Marginingsih (2016) charismatic leadership can influence the values of its members. The function of the leader is more to provide consultation, guidance, motivation and provide advice in order to achieve goals.

According to Kasmir (2016), many factors can affect employee performance, including leadership, job satisfaction, motivation, incentives. This is due to the fact that humans are creatures whose desires are unlimited, thus encouraging them to carry out their activities to meet the needs and satisfaction they want. The relationship between leadership and performance is highly dependent on the quality of leadership in the organization concerned (Dewi, 2017).

The phenomenon that occurs at PT. Austin Engineering Indonesia has employees who feel that their leaders are not really able to mingle with their employees, an attitude that is too monotonous, which makes employees also stiff. Employee lack of discipline in terms of work or lack of responsibility at work. The policies implemented by the leadership are sometimes only based on their own will without any absorption of aspirations from their subordinates.

Based on the description, it can be concluded that employee performance will be better if it is supported by increased work performance, appropriate incentives, and the existence of work discipline which is always implemented by employees of PT. Austin Engineering Indonesia. However, if the management of PT. Austin Engineering Indonesia is not sensitive to the work environment, such as work performance that is not rewarded, there is no incentive increase, lack of discipline in work, and a good and professional leadership style from superiors, so the performance of the employees of PT. Austin Engineering Indonesia will never do well.

On the basis of the above thinking, I am interested in conducting research with the title Effect of Work Performance, Incentives, Discipline and Leadership Style on Employee Performance.

\section{Literature Review}

\subsection{Job Performance}

Job performance is the result of a person's efforts which are determined by the ability of his personal characteristics and perceptions of his role in the job (Sutrisno, 2017). According to Mangkunegara (2016) work performance is the result of work in quality and quantity achieved by an employee in carrying out his duties in accordance with the responsibilities given.

Job performance is a result of work achieved by a person by carrying out the tasks assigned to him based on skills, experience, seriousness and time (Hasibuan 2016). According to As'ad (2014) work performance is quality, quantity, time used, position held, attendance, and safety in carrying out work. Which dimension is important is different from one job to another. From some of the definitions of work performance presented by the experts above, it can be concluded that work performance is the result of a person's efforts or sincerity in carrying out a job entrusted to him with his skills, experience, and sincerity in accordance with the responsibilities that have been given to him.

\subsection{Incentives}

According to Hasibuan (2016), the notion of incentives is additional remuneration given to certain employees whose performance is above standard performance. This incentive is a tool used by supporters of the fair principle in providing compensation. 
According to Sofyandi (2018), incentives are a form of direct compensation. Incentives are direct rewards paid to employees because their performance exceeds the specified standard.

According to Hariandja (2015). Incentives are one type of reward associated with work performance. The higher the work performance, the greater the incentive received. It has become a habit that every company must set high targets and if successful it will be given additional income. Incentives are another form of direct wages other than salaries and wages which are fixed compensation, which is called a performance-based compensation system (Pay for Performance Plan). Incentives are positive motivators for employees to increase their work enthusiasm, creativity and self-development towards professional workforce.

According to Hariandja (2014), incentives are used to encourage employees to improve the quality and quantity of their work. The provision of these incentives is beneficial for both the company and the employees. If the incentives received are not related to work performance, but are personal in nature, then they will feel that there is an injustice that can lead to dissatisfaction which in turn can affect behavior, such as absenteeism and decreased work performance.

\subsection{Discipline}

Sutrisno (2017), said: "In everyday life, wherever humans are, rules and regulations are needed that will regulate and limit every activity and behavior. However, these regulations have no meaning if they are not accompanied by sanctions for their customers".

Humans as individuals sometimes want to live freely, so they want to escape from all the bonds and regulations that limit their activities and behavior. But humans are also social creatures who live among other individuals, where they have a need to feel accepted by others.

The conformity of each individual with everything assigned to him will create a society that is orderly and free from confusion. Likewise, life in a company will really require the obedience of its members to the rules and regulations that apply to the company. In other words, work discipline for employees is needed, because what the company aims to achieve will be difficult to achieve if there is no work discipline.

Hasibuan (2016), states: "Discipline is the sixth operative function of human resource management. Discipline is the most important operational function of human resource management because the better the employee's discipline, the higher the work performance they can achieve. Without good employee discipline, it is difficult for corporate organizations to achieve optimal results.

\subsection{Leadership Style}

Leadership is one of the most important factors in an organization because most of the success and failure of an organization is determined by the leadership in the organization. Leadership is the backbone of organizational development because without good leadership it will be difficult to achieve organizational goals.

The discussion of leaders and leadership in general explains how to be a good leader, styles and traits that are in accordance with leadership and what conditions a good leader needs to have. Even so, it is still difficult to fully implement, so that in practice only a few leaders can carry out their leadership well and can bring their followers to the desired state.

Leadership can be categorized as applied social sciences. This is based on the premise that leadership with its principles has direct and indirect benefits to efforts to realize human welfare. According to Wahjosumidjo's (2017) opinion, leadership is the nature, character and personal qualities of a leader. The personal quality in question is the condition of a leader with the characteristics, temperament and traits he has. Not all leaders have leadership traits.

According to Tead's opinion in Kartono (2014), leadership is an activity that influences people to work together to achieve the goals they want. According to Anoraga and Widiyanti's (2015) opinion, leadership is a relationship where one person, namely the leader, influences other parties to work together voluntarily in an effort to carry out related tasks to achieve what the leader wants. Based on the above understanding, leadership describes a relationship and is significant. Someone with a group of people who both have the same interests and goals. In this case, this group of people considers that a person has special skills and advantages, so that a person can influence other people.

According to Wahjosumidjo (2015), what is meant by leadership is a form of relationship between a group of people, a relationship between those who lead and those who are led, where the relationship reflects a person or group of people behaving because of the authority or power that exists in the person who leads. Leadership in an institution, such as in a school environment, will have an impact on employee performance in relation to the work they do. When leaders as decision makers are wise and professional in leading their employees, it will affect the seriousness of employees in carrying out operational activities in the company.

Leadership style is behavior and strategy, as a result of a combination of philosophies, skills, traits, attitudes, which are often applied by a leader when he tries to influence the performance of his subordinates (Tampubolon, 2017). Leadership, like other sciences, has various functions, among others, presenting various matters relating to problems in leadership and providing influence in using various approaches in relation to solving various kinds of problems that may arise in leadership ecology. Leadership as a branch of science, which has an important role in the administrative process. This is based on the idea that the role of a leader is the implementation or translation of the leadership function. 
The leadership function is one of the roles of the administrator in order to influence other people or subordinates to be happy to achieve the organizational goals that have been previously set. Leadership style, contains the meaning as a manifestation of the behavior of a leader, which concerns his ability to lead. Democratic leadership style is a leader style that gives broad authority to subordinates. Every time there is a problem, always include subordinates as a whole team. In a democratic leadership style, the leader provides a lot of information about the duties and responsibilities of his subordinates.

In democratic leadership, members have a bigger role. In this leadership, a leader only shows the goals to be achieved, on how to achieve these goals, the members who determine. In addition, members are also given the freedom to solve the problems they face. Democratic leadership is suitable for highly competent members with varying commitments.

Based on the definition of leadership style above, it can be concluded that leadership is a person's ability to direct, influence, encourage and control other people or subordinates to be able to do work on their awareness and voluntarily in achieving a certain goal.

\subsection{Employee Performance}

According to Hasibuan (2016) explains that "Performance is the result of work achieved by a person in carrying out the tasks assigned to him based on skills, experience, seriousness and time". According to Prawirosentono (2018) "Performance or in English is performance", namely: Work results that can be achieved by a person or group of people in the organization, in accordance with their respective authorities and responsibilities in an effort to achieve the goals of the organization concerned legally, not violates the law and is in accordance with morals and ethics.

Based on some of the above definitions, it can be concluded that employee performance is the ability to achieve job requirements, where a work target can be completed at the right time or does not exceed the time limit provided so that the goal will be in accordance with company morals and ethics. Thus the employee's performance can contribute to the company.

In the Big Indonesian Dictionary quoted and translated by Nawawi (2016) says that "Performance is (a) something achieved, (b) demonstrated achievement, (c) work ability". Another definition of performance according to Nawawi (2016) is "Performance is said to be high if a work target can be completed at the right time or does not exceed the time limit provided".

Performance becomes low if it is completed beyond the allotted time limit or is not completed at all. According to Simamora, quoted and translated by Nurhayati (2018) "Employee performance is the level at which employees achieve job requirements".

\section{Methodology}

This research is a quantitative research. The study took the population at PT. Austin Engineering Indonesia. The number of employees in the Supply Chain Management section is 175 people, so this study is a population study. Therefore, the sample taken is a population of 75 employees of PT. Austin Engineering Indonesia in the Supply Chain Management section. Thus the sampling technique used in this study is saturated sampling technique.

\subsection{Data Collection Technique}

According to Sugiyono (2015) in quantitative research, there are two main things that affect the quality of research data, namely the quality of research instruments and the quality of data collection. The quality of the research instruments with regard to the validity and reliability of the instruments and the quality of data collection with regard to the accuracy of the methods used to collect data. This study uses a questionnaire as a data collection tool and uses a Likert scale.

\subsection{Data Analysis Technique}

The data analysis process is an activity after all data is collected from correspondents including grouping data based on variables and types of respondents, tabulating data based on variables from all respondents, presenting data for each variable studied, performing calculations to answer problem formulations and performing calculations to test the hypotheses that have been proposed (Sugiyono, 2015). This study analyzed the data using the SPSS 23 statistical test.

\section{Results}

Based on the data tabulated and then processed with statistical test tools, the results can be seen in the next explanation. The results of processed data to test the validity of each variable obtained the results of the r-count $>$ r-table 0.189 so that it was declared valid. In the reliability test, each variable has a Cronbach Alpa value $>0.60$ so that it is declared reliable. 
Table 1- Kolmogorov-Smirnov test results

\begin{tabular}{llr}
\hline \multicolumn{2}{c}{ One-Sample Kolmogorov-Smirnov Test } \\
\hline N & & \multicolumn{2}{c}{ Unstandardized } \\
& Residual \\
Normal Parameters & & 75 \\
& Mean & $0 \mathrm{E}-7$ \\
& Std. & 1.82778488 \\
Most Extreme Differences & Deviation & .115 \\
& Absolute & .075 \\
Kolmogorov-Smirnov Z & Positive & -.115 \\
Asymp. Sig. (2-tailed) & Negative & .889 \\
& & .420 \\
\hline
\end{tabular}

Source: Primary data processed, 2020

Analyzing the results of the Kolmogorov-Smirnov test in table 1 it can be concluded that the data is normally distributed because of the Asymp value. Sig. (2-tailed) has a significance level of $0.420>0.05$.

Table 2 - Multicollinearity test results

\begin{tabular}{cccc}
\hline Model & & \multicolumn{2}{c}{ Collinearity Statistics } \\
& & Tolerance & VIF \\
\hline \multirow{4}{*}{1} & Work Achievement & .421 & 4.113 \\
& Incentives & .315 & 5.647 \\
& Discipline & .333 & 5.287 \\
& Leadership Style & .684 & 2.712 \\
\hline \multicolumn{3}{c}{ Source: Primary data processed, 2020 }
\end{tabular}

Based on the multicollinearity test results in table 2 above, it appears that the VIF of each variable, namely work performance $(4,113)$, incentives $(5,647)$, discipline $(5,287)$ and leadership style $(2,712)$ is below the number 10 . While the tolerance value for work performance $(0.421)$, incentives $(0.315)$, discipline $(0.333)$ and leadership style $(0.684)$ are above 0.1 , so that the model does not have multicollinearity symptoms.

Table 3 - Glejser test results

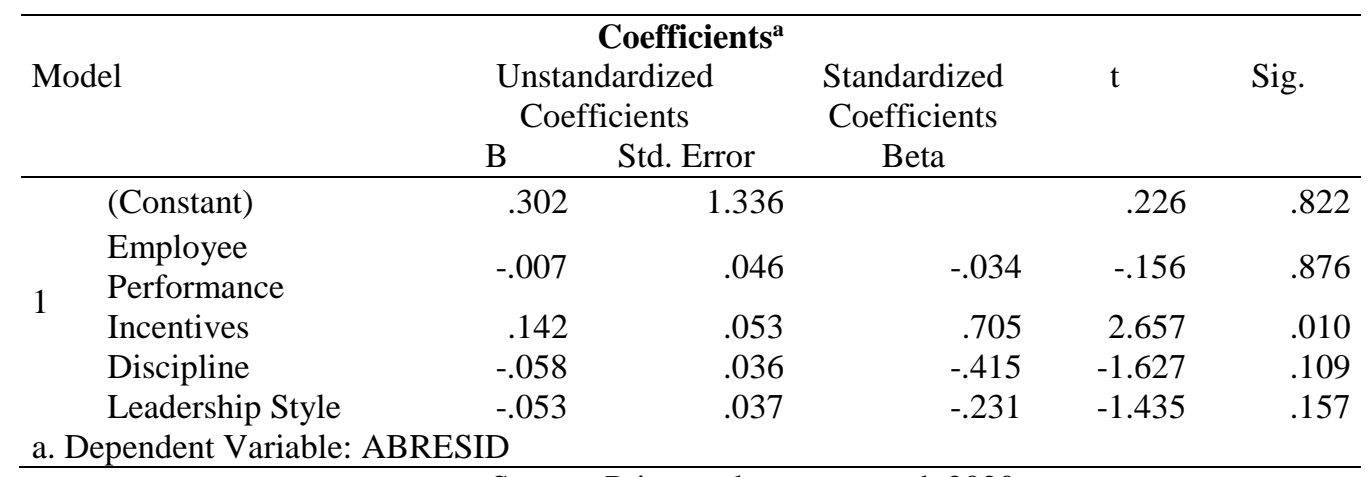

Source: Primary data processed, 2020

The results of the Glejser test in Table 3, the probability or significance level of the work performance variable, is $0.876>0.05$, the incentive variable is $0.010>0.05$, the discipline variable is $0.109>0.05$ and the leadership style variable is $0.157>0.05$ so it can be ascertained. The model does not experience heteroscedasticity symptoms, in other words the correlation of each variable with its residual value results in a value greater than alpha. 
Table 4 - T test results

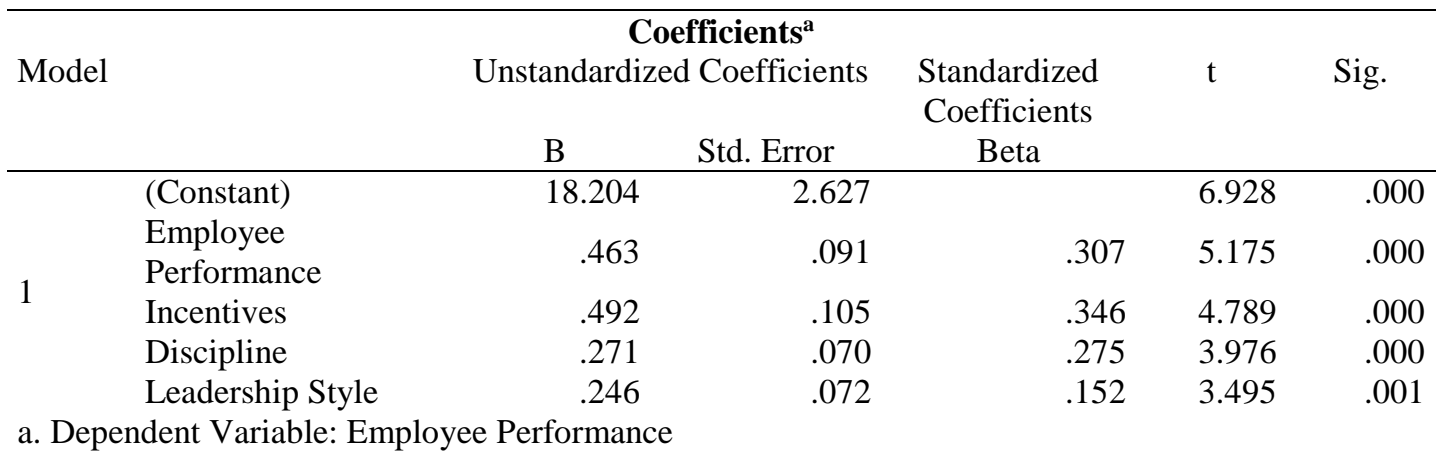

Source: Primary data processed, 2020

Based on the results of the $\mathrm{t}$ test in Table 4, the regression equation is as follows: $\mathrm{Y}=18.204+0.463 \mathrm{X} 1+0.492 \mathrm{X} 2+$ $0.271 \mathrm{X} 3+0.246 \mathrm{X} 4+\mathrm{e}$

\section{a. Effect of Job Performance on Employee Performance}

The value of t-count (5.175)> t-table (1.665), the significance value of $0.000<0.05$, then $\mathrm{H} 0$ is rejected, $\mathrm{H} 1$ is accepted. So the work performance variable has a significant effect on employee performance variables.

b. Effect of Work Incentives on Employee Performance

The value of t-count $(4,789)>\mathrm{t}$-table $(1,665)$, the significance value of $0.000<0.05$, then $\mathrm{H} 0$ is rejected, $\mathrm{H} 2$ is accepted. So the incentive variable has a significant effect on employee performance variables.

\section{c. The Effect of Discipline on Employee Performance}

The value of t-count (3.976)> t-table (1.665), the significance value of $0.000<0.05$, then $\mathrm{H} 0$ is rejected, $\mathrm{H} 3$ is accepted. So the discipline variable has a significant effect on employee performance variables.

\section{d. The Effect of Leadership Style on Employee Performance}

The value of t-count (3.495)> t-table (1.665), the significance value of $0.001<0.05$, then H0 is rejected, H4 is accepted. So the leadership style variable has a significant effect on employee performance variables.

Table 5 - F test results

\begin{tabular}{|c|c|c|c|c|c|c|}
\hline \multicolumn{7}{|c|}{ ANOVA $^{a}$} \\
\hline Model & & Sum of Squares & df & Mean Square & $\mathrm{F}$ & Sig. \\
\hline \multirow{3}{*}{1} & Regression & 2254.808 & 4 & 563.777 & 197.885 & $.000^{\mathrm{b}}$ \\
\hline & Residual & 161.731 & 57 & 2.936 & & \\
\hline & Total & 2416.439 & 61 & & & \\
\hline $\begin{array}{l}\text { a. Depe } \\
\text { b. Pred }\end{array}$ & $\begin{array}{l}\text { ent Variable: } \\
\text { rs: (Constant }\end{array}$ & $\begin{array}{l}\text { ployee Performan } \\
\text { Jork Achievemen }\end{array}$ & entives, & Discipline, Lead & ip Style & \\
\hline
\end{tabular}

The results of the f-test in Table 5, the value of f-count is 197,885, which means that the value is greater with the ftable is 2.49, so the decision $\mathrm{H} 0$ is rejected and $\mathrm{H} 5$ is accepted. This proves that work performance, incentives, discipline and leadership style affect the performance of employees of PT. Austin Engineering Indonesia.

Table 6 - Determination Test Results

\begin{tabular}{lcccc}
\hline \multicolumn{5}{c}{ Model Summary $^{\mathbf{b}}$} \\
Model & $\mathrm{R}$ & R Square & Adjusted R Square & Std. Error of the Estimate \\
\hline 1 & $.978^{\mathrm{a}}$ & .944 & .937 & 1.78393 \\
a. Predictors: (Constant), Work Achievement, Incentives, Discipline, Leadership Style & \\
b. Dependent Variable: Employee Performance & & \\
\hline
\end{tabular}

Source: Primary data processed, 2020

Based on the results of the determination test in Table 6 , the $\mathrm{R}$ number value is 0.978 , meaning that the correlation between the variables of leadership, job satisfaction, motivation and incentives on employee performance is $97.8 \%$. The value of determination (R2) obtained is 0.944 , this means that the percentage of the variable contribution of leadership, job satisfaction, motivation and incentives in the regression model is $94.4 \%$ and the relationship that occurs is very strong, while the remaining $5.6 \%$ is explained by other variables not examined or not included in this study. 


\section{Discussion and Suggestion}

The results of this study obtained the t-value for the work performance variable of 5,175 , which is greater than the $\mathrm{t}$-table of 1,665 and the significance value of 0,000 is less than 0.05. Based on the results obtained, $\mathrm{H} 0$ is rejected and $\mathrm{H} 1$ is accepted for work performance variables, thus partially the work performance variable has a positive and significant effect on employee performance at PT. Austin Engineering Indonesia. This research supports Wahyono's (2018) research.

The results of this study obtained the t-value for the incentive variable of 4,789, which is greater than the t-table of 1,665 and the significance value of 0,000 is less than 0.05 . Based on the results obtained, $\mathrm{H} 0$ is rejected and $\mathrm{H} 2$ is accepted for the incentive variable, thus partially the incentive variable has a positive and significant effect on employee performance at PT. Austin Engineering Indonesia. This research supports the research of Putra and Susanti (2018).

The results of this study obtained the t-value for the discipline variable of 3.976, greater than the t-table of 1.665 and a significance value of 0.001 less than 0.05. Based on the results obtained, H0 is rejected and $\mathrm{H} 4$ is accepted for the discipline variable, thus partially the discipline variable has a positive and significant effect on employee performance at PT. Austin Engineering Indonesia. This research supports the research of Jeffrey \& Soleman (2017), Isvandiari (2018), Perizade, Hanafi \& Reza (2018), and Ardianto (2020).

The results of this study obtained the t-value for the leadership style variable of 3.495 , greater than the t-table of 1.665 and the significance value of 0.001 less than 0.05 . Based on the results obtained, H0 is rejected and H4 is accepted for the discipline variable, thus partially the leadership style variable has a positive and significant effect on employee performance at PT. Austin Engineering Indonesia. This research supports the research of Nawongselngollan \& Roussel, (2017), Widodo, Alamsyah and Utomo (2018), and Darojat, Rahmat \& Djaafar (2019).

The results of this study indicate that the f-count value of 197,885 is greater than the f-table 2.49 and the significance level of 0.000 is less than 0.05. Based on the results obtained, H0 is rejected and H5 is accepted, thus the work performance variable, incentive variable, discipline variable and leadership style variable simultaneously have a positive effect on the employee performance of PT. Austin Engineering Indonesia. This research supports the research of Heriyanto (2018).

Based on the results of the study, suggestions are given for companies that want to improve employee performance. What must be done is that the company continues to provide work performance, pay attention to employee incentives, provide incentives to employees and provide good leadership styles to employees so that the main goals of the company can be achieved.

Employee performance is influenced by work performance, incentives, discipline and leadership style by $94.4 \%$, while the remaining $5.6 \%$ is influenced by other variables not examined in this study. It is expected that further research can add other variables that can affect employee performance. To all company leaders in order to improve communication, skills and supervision of employees so that a good solution is obtained in the working relationship between employees and leaders. The company should pay more attention to the normative rights of employees and other benefits that are adjusted to their duties.

\section{Conclusion}

Based on the results and discussion described above, it can be concluded that job performance has a positive and significant effect on employee performance. Incentives have a positive and significant effect on employee performance. Discipline has a positive and significant effect on employee performance. Leadership style has a positive and significant effect on employee performance. Work performance, incentives, discipline and leadership style simultaneously have a significant effect on employee performance.

\section{Acknowledgment}

The author would like to express their gratitude to Universitas Riau Kepulauan, Batam, Indonesia for the assistance and the information provided to ensure the success of the study.

\section{References}

[1] Edelman P, \& van Knippenberg D 2018 Emotional intelligence, management of subordinate's emotions, and leadership effectiveness Leadership \& Org. Dev. J

[2] Di Fabio A, \& Saklofske D H 2018 The contributions of personality and emotional intelligence to resiliency Personality and Individual Differences vol 123 p 140-144

[3] Baesu C 2019 Leadership based on emotional intelligence in modern organizations The USV Annals of Economics and Public Administration Vol 18 p 73-78

[4] Kim J I 2018 The Effects of Emotional Intelligence, Self-Leadership, Psychological Well-being to Academic Achievement of Nursing College Student J. of the Korea Academia-Industrial cooperation Society Vol 19(12) p 574-583

[5] Siegler R 1992 The other Alfred Binet Developmental Psychology Vol 28(2) p 178-190 
[6] Wills A 2018 Emotional and spiritual intelligence in the workplace in relation to organizational citizenship behavior (Doctoral dissertation, Kaplan University)

[7] Rathore S, \& Pandey R 2018 Reviewing emotional intelligence with leadership theory: a study of the role of emotional intelligence on transformational leadership In Management Strategies and Technology Fluidity in the Asian Business Sector p 1-13 IGI Global

[8] Wang L, Tao H, Bowers B J, Brown R, \& Zhang Y 2018 When nurse emotional intelligence matters: How transformational leadership influences intent to stay J. of nursing management, Vol 26(4) p 358-365

[9] Makkar S, \& Basu S 2019 The impact of emotional intelligence on workplace behaviour: A study of bank employees Global Business Review Vol 20(2) p 458-478

[10] Pool L D, \& Qualter P 2018 An introduction to emotional intelligence John Wiley \& Sons

[11] Prezerakos P E 2018 Nurse managers' emotional intelligence and effective leadership: A review of the current evidence The open nursing journal Vol 12 p 86

[12] Suwandana I G M 2019 Role of transformational leadership mediation: effect of emotional and communication intelligence towards teamwork effectiveness Int. research j.l of management, IT and social sciences Vol 6(2) p 5262

[13] Lussier R 2012 Human relations in organizations: Applications and skill building McGraw-Hill Higher Education

[14] Caldwell C 2012 Moral Leadership: A Transformative Model for Tomorrow's Leaders Business Expert Press

[15] Kouzes J M, \& Posner B Z 2012 The Leadership Challenge: How to Make Extraordinary Things Happen in Organizations Jossey-Bass.

[16] DePree M 2011 Leadership is an art Crown Business

[17] Paine L 2002 Value shift: Why companies must merge social and financial imperatives to achieve superior performance McGraw Hill Professional

[18] Hernandez M 2012 Toward an understanding of the psychology of stewardship. Academy of Management Review vol 37(2) p172-193

[19] Treviño L K, Hartman L P, \& Brown M 2000 Moral person and moral manager: How executives develop a reputation for ethical leadership California management review vol 42(4) p 128-142

[20] Cameron K 2011 Responsible leadership as virtuous leadership Journal of Business Ethics Vol 98(1) p25-35

[21] Shao R, Aquino K, \& Freeman D 2008 Beyond moral reasoning: A review of moral identity research and its implications for business ethics Business Ethics Quarterly vol 18(04) p 513-540

[22] Hosmer L T, \& Hosmer L R T 2010 The ethics of management (p. 169) Homewood IL Irwin.

[23] Lennick D, \& Kiel F 2008 Moral Intelligence: Enhancing Business Performance \& Leadership Success (Wharton Business School Publishing, Upper Saddle River, NJ)

[24] Covey S R 2013 The 8th habit: From effectiveness to greatness Simon and Schuster

[28] Kunnanatt J T 2004 Emotional intelligence: The new science of interpersonal effectiveness. Hum. Resour. Dev. Q. p 489-495. doi: 10.1002/hrdq.1117.

[29] Goleman D 2001 Emotional intelligence: Issues in paradigm building In The Emotionally Intelligent Workplace: How to Select for, Measure, and Improve Emotional Intelligence in Individuals, Groups, and Organizations Vol 13 Jossey-Bass San Francisco CA, USA p. 26.

[30] Goleman D P 1995 Emotional Intelligence: Why it Can Matter More than IQ for Character, Health and Lifelong Achievement Bantam Books New York USA

[25] Mayer J D, Roberts R D, Barsade S G 2008 Human abilities: Emotional intelligence. Annu. Rev. Psychol. Vol 59 p 507-536. doi: 10.1146/annurev.psych.59.103006.093646.

[26] Gutiérrez-Cobo M J, Cabello R, Fernández-Berrocal P 2016 The relationship between emotional intelligence and cool and hot cognitive processes: A systematic review Front. Behav. Neurosci. Vol 10 p 101

[27] Salovey P, Mayer J D 1990 Emotional intelligence Imagin. Cogn. Personal vol 9 p 185-211. doi: 10.2190/DUGGP24E-52WK-6CDG

[31] Mayer J D, Salovey P, Caruso D R, Sitarenios G 2003 Measuring emotional intelligence with the MSCEIT V2. 0. Emotion. Vol 3 p 97-105

[32] Mayer J D 2000 Emotion, intelligence, and emotional intelligence In: Forgas JP editor Handbook of Affect and Social Cognition. Erlbaum; Mahwah, NJ, USA p 410-431.

[33] Bar-On R 2006 The Bar-On model of emotional-social intelligence (ESI) Psicothema vol 18 p 1- 28

[34] Klemp G 2005 Emotional intelligence and leadership: What really matters Boston, MA: Cambria Consulting, Inc.

[35] McKenney S E, \& Reeves T C 2012 Conducting educational research design: What, why and how Taylor \& Francis 